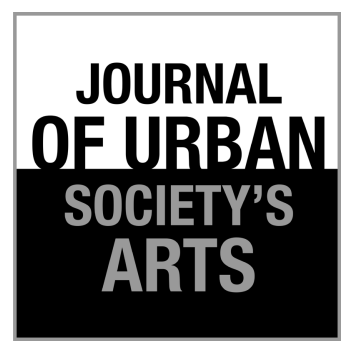

Volume 1 Nomor 1 , April 2014: 17-26

\title{
Kajian Aspek Ketidaksadaran dalam Karya Seni Rupa Indonesia Periode 2000-2011
}

Irma Damajanti, Setiawan Sabana, dan Ira Adriati

Fakultas Seni Rupa dan Desain, Institut Teknologi Bandung

Jln. Ganesa No. 10 Bandung 40132

Tlp.08122122991, E-mail: irmadamajanti@yahoo.com

\begin{abstract}
ABSTRAK
Pada era seni rupa kontemporer, pembacaan karya tidak lagi hanya terbatas pada hasil analisis dan interpretasi unsur-unsur formal, namun juga mempertimbangkan keterkaitannya dengan psikobiografi seniman sehingga dapat memberikan gambaran yang lebih lengkap tentang karakter seni rupa yang multifaset. Penelitian ini dirancang untuk mengidentifikasi representasi aspek ketidaksadaran dalam karya seni rupa Indonesia dan menginterpretasikan simbol-simbolnya. Seniman yang karyanya dipilih sebagai studi kasus dalam penelitian ini adalah I Gusti Ayu Kadek Murniasih, Entang Wiharso, dan Ugo Untoro. Pendekatan yang digunakan adalah pendekatan multidisiplin (psikologi seni dan semiotika. Berdasarkan hasil analisis, aspek ketidaksadaran yang direpresentasikan melalui simbol-simbol visual yang khas dalam karya ketiga seniman cenderung lahir dari pengalaman traumatik yang melahirkan ketakutan, kesakitan, dan agresi. Melukis bagi ketiganya adalah proses katarsis, media untuk mensublimasikan/memperhalus dorongan-dorongan naluri ketakutan, kesakitan, dan agresi ke dalam bentuk karya yang dapat diterima dan diapresiasi dengan baik oleh masyarakat.
\end{abstract}

Kata kunci: ketidaksadaran, seni rupa, sublimasi, dorongan naluri

\begin{abstract}
A Study on Unconsciousness Aspect in the 2000-2011 Works of Indonesia Visual Art. In the era of contemporary visual art, the works of art cannot be read merely limited to the analysis and interpretation of the formal elements but have to include the consideration about the artist's psychobiography so that there will be a more complete picture about the multifaceted visual arts. This research is carried out to identify the representation of the unconsciousness aspect in the works of visual arts and then interpret the symbols. The selected samples are the works of I Gusti Ayu Kadek Murniasih, Entang Wiharso, and Ugo Untoro. The multidisciplinary (art psychology and semiotics) approach is applied within the qualitative method used. Based on the analysis result, the unconsciousness aspect represented in unique visual symbols in the works of the three artists is originated in their traumatic experiences which generate fear, pain, and aggression. For them, painting is their catharsis process, the media to sublimelsmoothen their impulse of fear, pain, and aggression so that the society can accept and appreciate their works.
\end{abstract}

Keywords: unconsciousness, visual art, sublimation, impulse 


\section{Pendahuluan}

Sebelum lahirnya ilmu sejarah seni, filsafat menjadi satu-satunya alat untuk membedah seni dan tanggapan estetik. Namun, bagi sejarah seni penilaian terhadap nilai-nilai estetik bukanlah persoalan pokok. Sejarah seni secara tradisional difokuskan pada identifikasi, pencatatan, dan karakteristik karya atau sekelompok karya tertentu. Sejarah seni berkenaan dengan karya-karya — baik yang kuno maupun yang kontemporer- yang menimbulkan pertanyaan baru tentang sifat dan definisi seni. Ada masa ketika identitas seniman dari masyarakat dan periode waktu tertentu tidak diketahui sehingga salah satu fungsi sejarah seni adalah menentukan pertalian — mencocokkan nama seniman dengan karya seni dari tempat dan waktu tertentu. Pada abad ke-20, ketika modernisme turut berpengaruh terhadap perkembangan seni rupa dan keindahan tidak lagi menjadi tujuan, berkembang upayaupaya untuk mencari pemahaman falsafi atas seni dengan memanfaatkan ilmu-ilmu yang relevan untuk menerangi arti seni dan perannya dalam peradaban manusia, seperti ilmu-ilmu sosial, psikologi, semiotika, dan antropologi. Sejak itulah sejumlah pendekatan metodologis terhadap karya seni mulai dikembangkan, dan memberikan beragam cara yang berbeda untuk memikirkan seni, karya seni, seniman, dan bahkan kritikus. Laurie Schneider Adams (1996: 4) menguraikan beberapa metode analisis, di antaranya formalisme, marxisme, feminisme, semiotika, dan psikoanalisis.

Psikologi seni adalah salah satu pendekatan yang dapat membantu memberikan jawaban atas pertanyaan-pertanyaan yang menyangkut seniman -seperti motivasi artistik, proses kreasi, faktor pribadi dalam seni- di samping juga membantu memahami pengalaman estetik atau pengalaman seni bagi publik seni atau apresiator. Salah satu metode yang lahir dari displin ilmu ini adalah psikoanalisis, yang terutama berkaitan dengan arti ketaksadaran (unconsciousness) dalam karya seni. Psikoanalisis merupakan metode rumit yang melibatkan tidak hanya seni, namun juga seniman, tanggapan artistik apresiator, dan kritikus. Bagaimanapun, dengan menganalisis pembentukan pribadi, psikoanalisis juga membantu memahami pembentukan ideologi secara lebih luas, dan karenanya dapat diperluas untuk menganalisis sejumlah fenomena sosial dan kebudayaan. Psikologi seni dan metode psikoanalisis membuka peluang untuk mengelaborasi aspek ketidaksadaran seniman dan bagaimana representasinya dalam karya seni rupa. Pembacaan karya tidak lagi hanya terbatas pada hasil analisis dan interpretasi unsur-unsur formal, namun juga mempertimbangkan keterkaitannya dengan psikobiografi seniman sehingga dapat memberikan gambaran yang lebih lengkap tentang karakter seni rupa yang multifaset.

Berdasarkan pengamatan, sejauh ini belum banyak penelitian di Indonesia yang mengaplikasikan pendekatan psikologi seni dan metode psikoanalisis. Sebagian besar penelitian di bidang seni lebih sering mengangkat topik tentang karya seni - yang memang merupakan pokok persoalan seni- termasuk di Indonesia. Kalaupun ada peneliti yang memfokuskan penelitiannya terhadap aspek personal seniman, jumlahnya masih relatif sedikit. Padahal dalam era seni rupa kontemporer sekarang ini, karya seni diyakini memiliki makna dan kekhasan berdasarkan konteks sosial-budayanya, serta memiliki potensi untuk ditafsirkan secara berbeda dalam berbagai rentang waktu dan tempat. Dengan demikian, dalam menilai sebuah karya seni pun cenderung untuk mempertimbangkan perbedaan-perbedaan kepribadian (personality differences), latar belakang sosial-ekonomi, gender, dan afiliasi antara seniman dan apresiatornya; halhal yang sebelumnya tidak pernah diungkap dalam seni rupa modern yang hanya berfokus pada objek seni itu sendiri (Barrett, 1994:121).

Berdasarkan pemaparan tersebut, penelitian ini dirancang untuk mengidentifikasi representasi aspek ketidaksadaran dalam karya seni rupa Indonesia dan menginterpretasikan simbol-simbol ketidaksadaran yang direpresentasikannya. Objek kajian dalam penelitian ini adalah karya seni rupa Indonesia periode 2000-2011, yang dibatasi pada karya-karya dua dimensi dengan medium konvensional seni lukis dari para seniman yang berdasarkan konsensus medan sosial seni (artworld) di Indonesia dinilai sebagai leading artist berdasarkan parameter kontinuitas dan konsistensi dalam berkarya (minimal sudah berkarya selama 
tiga dekade), intensitas pameran (pameran tunggal maupun pameran bersama, baik di tingkat nasional maupun internasional), dan pengakuan dari komunitas seni rupa internasional. Berdasarkan parameter tersebut diinventarisasi karya-karya seni rupa yang dinilai memenuhi kriteria, dan kemudian disaring kembali menjadi beberapa sampel yang dianggap cukup mewakili. Berdasarkan kriteria tersebut, seniman yang karyanya akan dipilih untuk studi kasus dalam penelitian ini adalah: (1) I Gusti Ayu Kadek Murniasih (1966-2006), (2) Entang Wiharso (lahir 1967), dan (3) Ugo Untoro (lahir 1970).

Pengetahuan tentang metodologi penelitian/ pendekatan keilmuan membekali peneliti dengan alat-alat (tools) yang akan membantu membuat observasi secara objektif. Pendekatan yang akan digunakan dalam penelitian ini adalah pendekatan multidisiplin (psikologi seni dan semiotika) dengan menggunakan metoda kualitatif. Metoda kualitatif pada umumnya berorientasi pada eksplorasi, pengungkapan, dan logika induktif. Rancangan penelitian secara induktif diawali dengan pengamatan yang spesifik dalam membangun suatu pola umum. Kategori atau dimensi analisis muncul dari pengamatan yang bersifat terbuka (open-ended).

\section{Psikoanalisis}

Psikoanalisis merupakan salah satu aliran besar dalam sejarah ilmu pengetahuan manusia. Layaknya aliran besar lainnya, Marxisme contohnya, psikoanalisis telah merambah berbagai sektor keilmuan seperti sastra, sosiologi, filsafat, dan kesenian. Psikoanalisis awalnya identik dengan nama pendirinya, Sigmund Freud, sehingga penggunaan istilah psikoanalisis dan psikoanalisis Freud awalnya memiliki arti yang sama. Namun, kemudian beberapa murid Freud yang beralih dari ajaran gurunya memilih untuk meninggalkan istilah psikoanalisis; seperti Carl Gustav Jung yang memilih menggunakan nama psikologi analitis (analytical psychology) dan Alfred Adler dengan istilah psikologi individual (individual psychology). Seiring meluasnya penerimaan psikoanalisis dalam ruang keilmuan yang beragam, istilah tersebut akhirnya tidak hanya identik dengan Freud.

Psikoanalisis kali pertama dikembangkan di
Wina pada tahun 1890-an oleh Sigmund Freud (1947), seorang akhli syaraf berkebangsaan Austria yang memiliki ketertarikan untuk menemukan suatu penanganan yang efektif bagi para pasien dengan gejala neurosis atau histeris. Dari hasil perbincangannya dengan para pasien tersebut Freud menjadi yakin bahwa tindakan dan perilaku individu saat ini dipicu oleh trauma kejiwaan pada masa sebelumnya. Freud menyimpulkan bahwa pikiran manusia jauh lebih rumit daripada anggapan yang berkembang selama ini, dan kerumitan inilah yang mendorong banyak manusia untuk membentuk pemikiran-pemikiran yang tidak dapat diterima secara sosial atau membuat keputusan yang berbahaya. Bentuk asli psikoanalisis Freud sangat terfokus pada fantasi seksual yang ditekan oleh pasien dan pengalaman pada awal masa kanakkanak. Freud berharap dapat membantu pasiennya berhadapan dengan kenangan-kenangan traumatis dalam lingkungan yang aman untuk memahami kesulitan-kesulitannya (Adams, 1996:180).

Berikut ini adalah ilustrasi tentang pandangan Freud mengenai pikiran manusia (buman mind) yang dianalogikannya bagaikan sebongkah gunung es yang terapung-apung di tengah lautan, di antara kesadaran (consciousness) dan ketaksadaran (unconsciousness):

\section{PERS 5 Freud's View of the Human Mind: The Mental Iceberg}

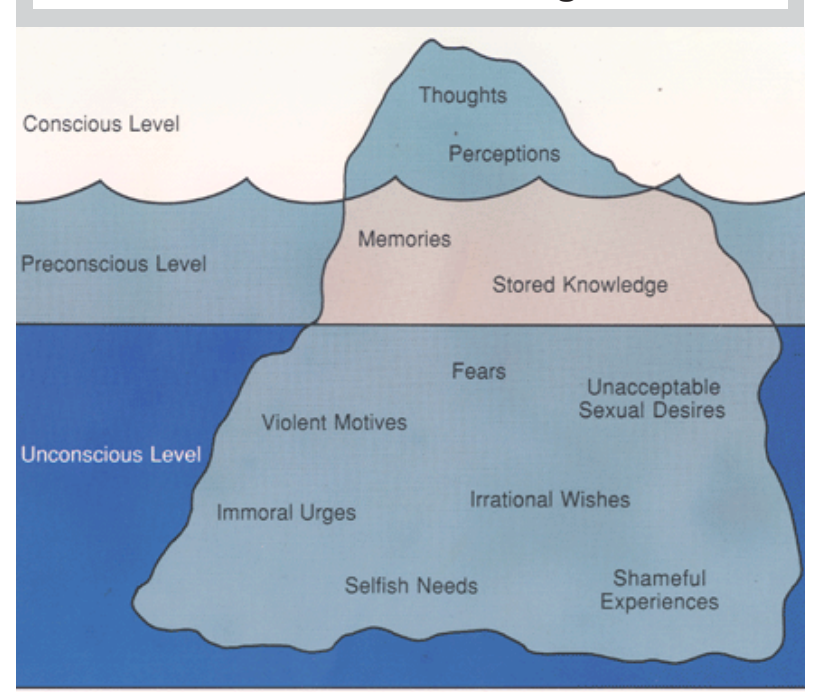

Gambar 1. Gagasan Freud tentang pikiran (mind) sebagai sebuah gunung es.

(Sumber: http//www.faculty.knox.edu) 
Menurut Freud, hasrat naluriah yang menuntut pelampiasan terutama bersifat seksual (biologis) dan timbul dari tahun-tahun awal masa kanakkanak. Melalui analisisnya terhadap para pasien dan dirinya sendiri, Freud percaya bahwa peristiwa yang menimpa seorang anak selama lima tahun pertama dalam kehidupannya akan membentuk kepribadiannya pada masa dewasa.

Seperti halnya kreativitas, neurosis pun berasal dari tanggapan terhadap konflik antara tekanan kekuatan naluri yang tidak biasa dan tuntutan masyarakat yang menghalangi pemenuhan hasrat-hasrat naluriah tersebut. Baik neurosis maupun kreativitas mencoba menyelesaikan konflik tersebut. Penderita neurosis bereaksi terhadap konflik dengan membuat mekanisme pertahanan yang menekan dan mengubah hasratnya, seringkali menghasilkan kepribadian yang relatif rapuh. Orang kreatif tidak menekan hasrat naluriah yang secara sosial tidak diterima; malahan menghaluskannya. Dalam upaya menghaluskan (sublimation), kekuatan yang bersifat libido tidak ditekan melainkan diubah salurannya untuk mengisi tujuantujuan yang dapat diterima masyarakat. Tujuantujuan yang disetujui masyarakat ini tidak terbatas pada bidang seni: seorang atlet yang berusaha untuk bertanding di Olimpiade sama halnya dengan seniman yang berusaha menghasilkan karya seni.

Freud tidak hanya percaya bahwa dorongan mencipta ditentukan oleh konflik bawah sadar pada masa awal kanak-kanak, dia juga merasa bahwa muatan karya seni, seperti halnya mimpi, juga ditentukan dengan cara yang sama. Karena fungsi karya seni merupakan pemenuhan keinginan bawah sadar masa kanak-kanak yang tersembunyi, karya diinterpretasikan sebagaimana mestinya, menjadi sebuah jendela dari ketaksadaran. Dengan menganalisis muatan karya seni dan membandingkan simbol-simbol tersembunyi di baliknya dapat membuka kepribadian seniman (Winner, 1996: 18-19).

\section{Semiotika}

Semiotika adalah sebuah cabang keilmuan yang memperlihatkan pengaruh semakin penting sejak empat dekade yang lalu, tidak saja sebagai 'metoda kajian' (decoding), akan tetapi juga sebagai 'metode penciptaan' (encoding). Semiotika telah berkembang menjadi sebuah 'model' atau 'paradigma' bagi bidang-bidang keilmuan yang sangat luas, yang menciptakan cabang-cabang semiotika khusus, di antaranya adalah semiotika binatang (zoo semiotics), semiotika kedokteran (medical semiotics), semiotika arsitektur, semiotika desain, semiotika fashion, semiotika film, semiotika sastra, semiotika televisi, dan termasuk semiotika seni.

'Semiotika' (semiotics) didefinisikan oleh Ferdinand de Saussure (1990: 15) di dalam Course in General Linguistics, sebagai "ilmu yang mengkaji tentang tanda sebagai bagian dari kehidupan sosial" Implisit dalam definisi Saussure adalah prinsip, bahwa semiotika sangat menyandarkan dirinya pada aturan main (rule) atau kode sosial (social code) yang berlaku di dalam masyarakat, sehingga tanda dapat dipahami maknanya secara kolektif.

Saussure juga menjelaskan perbedaan antara dua model analisis dalam penelitian bahasa, yaitu analisis 'diakronik' (diachronic) dan analisis 'sinkronik' (synchronic). Analisis 'diakronik' adalah analisis tentang perubahan historis bahasa, yaitu bahasa dalam dimensi waktu, perkembangan dan perubahannya. Analisis 'sinkronik', adalah analisis yang di dalamnya kita mengambil 'irisan sejarah' dan mengkaji struktur bahasa hanya pada satu momen waktu tertentu saja, bukan dalam konteks perubahan historisnya. Apa yang disebut pendekatan 'strukturalisme' (structuralism) dalam bahasa, adalah pendekatan yang melihat hanya 'struktur' bahasa, dan mengabaikan konteks waktu, perubahan, dan sejarahnya.

Metode semiotika pada dasarnya beroperasi pada dua jenjang analisis. Pertama analisis tanda secara individual, misalnya jenis tanda, mekanisme, atau struktur tanda, dan makna tanda secara individual. Kedua, analisis tanda sebagai sebuah kelompok atau kombinasi, yaitu kumpulan tanda yang membentuk apa yang disebut sebagai 'teks' (text). 'Teks' dalam pengertiannya yang paling sederhana adalah "kombinasi tandatanda" (Thwaites, 1994: 68). Tipe-tipe teks yang paling jelas adalah kalimat yang ditulis di dalam sebuah novel, atau fashion yang dikenakan oleh seseorang. Masing-masing teks ini mempunyai aksis paradigmatik dan sintagmatiknya yang 
khusus. Kata-kata dalam novel atau unsur-unsur pakaian dalam fashion dapat dianggap sebagai kumpulan tanda-tanda, yang secara bersama-sama membentuk verbal text dan fashion text. Dalam pengertian yang sama, karya seni rupa dapat dianggap sebagai sebuah 'teks' karena ia merupakan 'kombinasi elemen tanda-tanda', dengan kode dan aturan tertentu sehingga menghasilkan sebuah ekspresi bermakna'. Pendekatan semiotika yang akan digunakan dalam penelitian ini adalah pendekatan strukturalisme dengan metode analisis teks visual.

\section{Seni Rupa Kontemporer Indonesia Era 2000-an} Seni rupa kontemporer era 2000-an hadir dalam dimensi sosial budaya yang berbeda dengan era sebelumnya (1990-an) yang mempunyai kecenderungan karya-karya instalatif dengan subject matter kritik sosial dan politik; kecenderungan yang memuncak pada akhir 1990-an seiring dengan berubahnya kondisi sosial politik Indonesia pada era Reformasi tahun 1998. Seni rupa era 2000 praktis merupakan situasi yang baru. Ketegangan sosial-politik yang banyak melatarbelakangi situasi sosial era 1990 -an berubah ke arah penataan pranata sosial. Situasi penataan pranata sosial juga mengubah orientasi masyarakat pada perbaikan sistem demokrasi dan ekonomi sehingga karyakarya seni yang muncul sejak era 2000-an tidak lagi banyak menyampaikan isu-isu dan kritik politik.

Perkembangan ekonomi dunia, khususnya Asia yang ditandai dengan kebangkitan ekonomi Cina, turut mendorong gairah ekonomi di Indonesia. Hal ini juga banyak berdampak dengan tumbuhnya unsur-unsur medan sosial seni rupa era 2000. Jumlah pameran yang meningkat baik untuk tingkat nasional dan internasional yang banyak didorong oleh keterlibatan pelaku seni sektor swasta, turut mendorong sistem produksi seni yang baru dan pendekatan banyak media seni yang muncul secara demokratis.

Perubahan situasi seni rupa kontemporer Indonesia era 2000 yang banyak didorong oleh perkembangan ekonomi banyak menghadirkan seniman-seniman era 90-an dan seniman generasi baru era 2000 dalam bentuk-bentuk ekspresi baru melalui pendekatan media yang beragam. Turut mendorong kecepatan perkembangan tersebut adalah unsur-unsur pelaku medan sosial seni yang melihat peluang ekonomi dalam sistem produksi seni tersebut. Kemunculan kolektor-kolektor baru, galeri baru, majalah-majalah seni dan balai lelang, bahkan keikutsertaan banyak galeri dan seniman ke sistem perdagangan seni internasional atau artfair menunjukkan peningkatan signifikan produktivitas seni rupa kontemporer Indonesia. Oleh karena itu, sejak tahun 2005 banyak kalangan menyebut kondisi ini sebagai boom seni rupa kontemporer Indonesia.

Tahun 2000-an menunjukkan gejala yang sama seperti era boom seni lukis tahun 1980-an. Gejala berkembangnya medan sosial seni rupa Indonesia dan perkembangan baru pasar seni lukis kontemporer memunculkan pertanyaan eksistensi media ekspresi nonlukis bagi seniman dan publiknya. Hal tersebut menunjukkan gejala pergeseran sekaligus wacana baru seni rupa kontemporer Indonesia, khususnya melihat kehadiran beragam media yang ditampilkan oleh seniman.

\section{Pembahasan}

Berdasarkan hasil identifikasi, berikut ini akan dibahas mengenai aspek-aspek ketidaksadaran dalam karya seni rupa Indonesia periode 2000-2011 dan interpretasi dari simbol-simbol ketidaksadaran yang direpresentasikannya. Berdasarkan hasil identifikasi, berikut ini akan dibahas mengenai aspek-aspek ketidaksadaran dalam karya seni rupa Indonesia periode 2000-2011 dan interpretasi dari simbol-simbol ketidaksadaran yang direpresentasikannya.

\section{Aspek Ketidaksadaran dalam Karya Seni Rupa Indonesia Periode Tahun 2000-2001}

I Gusti Ayu Kadek Murniasih, akrab dipanggil Murni, lahir di Tabanan, Bali, pada tanggal 21 Mei 1966 sebagai anak bungsu dari 10 bersaudara. Karya Murni banyak diilhami oleh masa lampaunya yang sangat menyakitkan. Pada usia sembilan tahun, ia mengalami pelecehan seksual oleh ayah kandungnya sendiri. Sejak itu ia menyadari betapa besar pengaruh peristiwa tersebut terhadap 


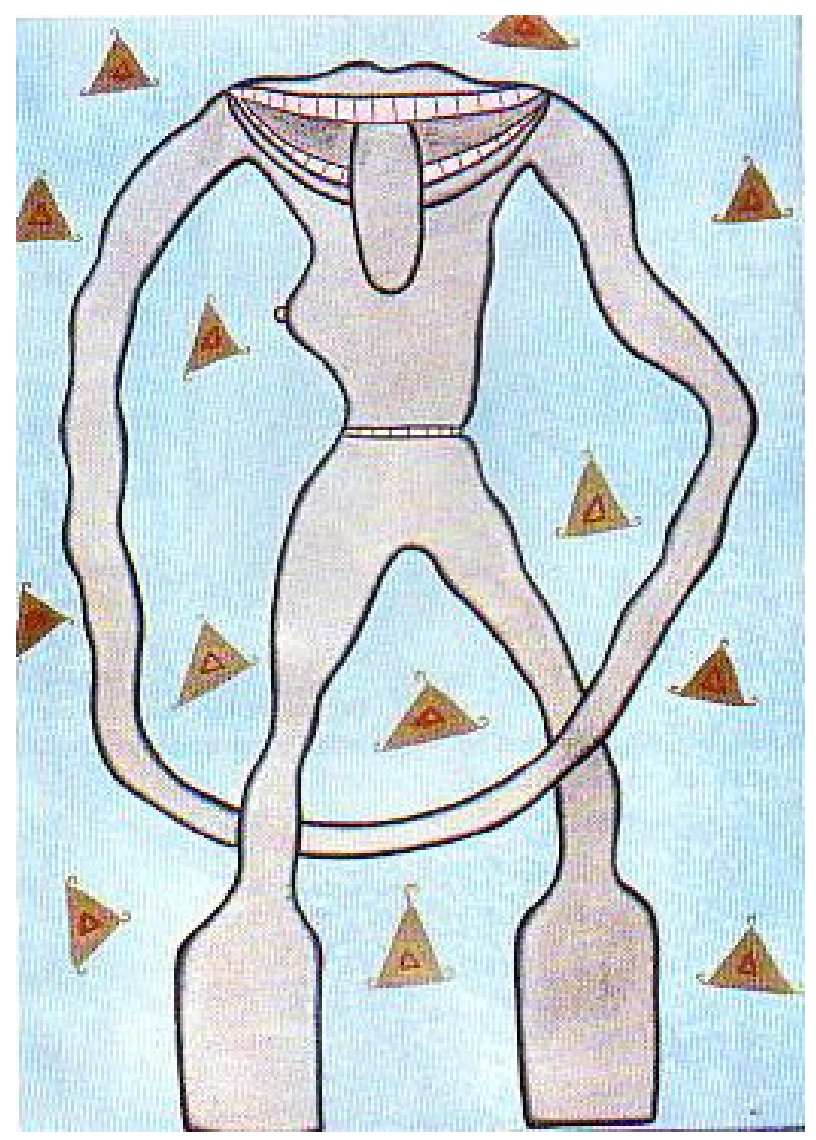

Gambar 2. I GAK Murniasih, I am a Strong-Body Woman, akrilik di atas kanvas (2000).

(Sumber: dokumentasi Adriati, 2010)

jiwanya. Kesakitannya ia ekspresikan di atas kanvas dengan gaya fantasi yang khas. Tahun 1992 bakatnya yang luar biasa mulai dikenal oleh medan sosial seni rupa di Bali, terutama terkait dunia khayalan dan eksistensinya sebagai perempuan. Sejak tahun 1995 ia terlibat dalam sejumlah kegiatan pameran bersama, baik di Indonesia maupun di luar negeri. Murni meninggal dunia pada tanggal 11 Januari 2006 di Ubud, Bali, karena penyakit kanker yang diidapnya.

Melalui gaya fantasinya yang khas Murni menentang aturan-aturan melukis tradisional, menciptakan karya seni yang tidak mungkin dilakukan seniman Bali lainnya. Farah Wardani, ahli sejarah seni Indonesia, menyatakan bahwa dalam alam masyarakat Bali di mana seks merupakan obsesi dan sebuah komoditas, dan tubuh perempuan cenderung dianggap suci dalam penjara passive nascissism, karya Murni mengingatkan kita pada sisi lain dari seksualitas perempuan — hasrat narsisis untuk memperoleh kuasa kembali terhadap tubuh

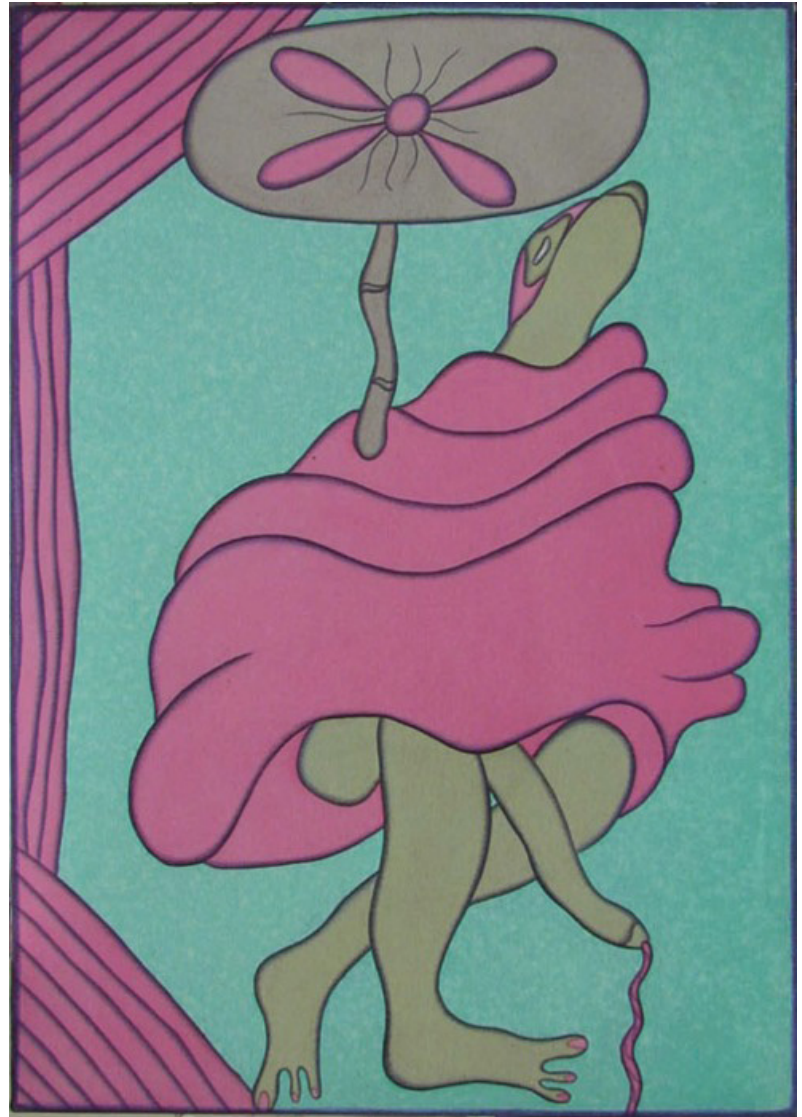

Gambar 3. I GAK Murniasih, 16 April 2000, akrilik di atas kanvas (2000). (Sumber: Photo courtesy of IVAA, http://arsipfarahwardani.tumblr.com)

pribadi. Dalam pandangan psikoanalisis Lacanian, hasrat atau desire dilihat sebagai mekanisme psikis yang tujuannya adalah mencari kepuasan (pleasure). Salah satu dari empat wacana tentang hasrat (discourse of desire) menurut Lacan adalah passive narcissism, yaitu hasrat menjadi objek cinta dari sesuatu (orang lain, kampung halaman, bangsa, negara, Tuhan), dengan men-setting diri (tindakan, perilaku, amal, perbuatan) agar 'the other' itu benar-benar mencintai kita. Dalam hal ini, Murni memiliki kuasa terhadap tubuhnya pribadi dan menolak untuk menjadi objek cinta atau tatapan 'the other', dalam hal ini kaum laki-laki.

Beberapa penulis dan pengamat seni kerap menggolongkan karya-karya Murni ke dalam kategori "feminist art", namun dalam sebuah wawancara dengan Carla Bianpoen, Murni secara jujur menyatakan bahwa yang ingin dilakukannya hanyalah melukis untuk menyingkirkan pengalaman traumatiknya pada masa kecil. Dengan melukis dia juga merasa eksis. 


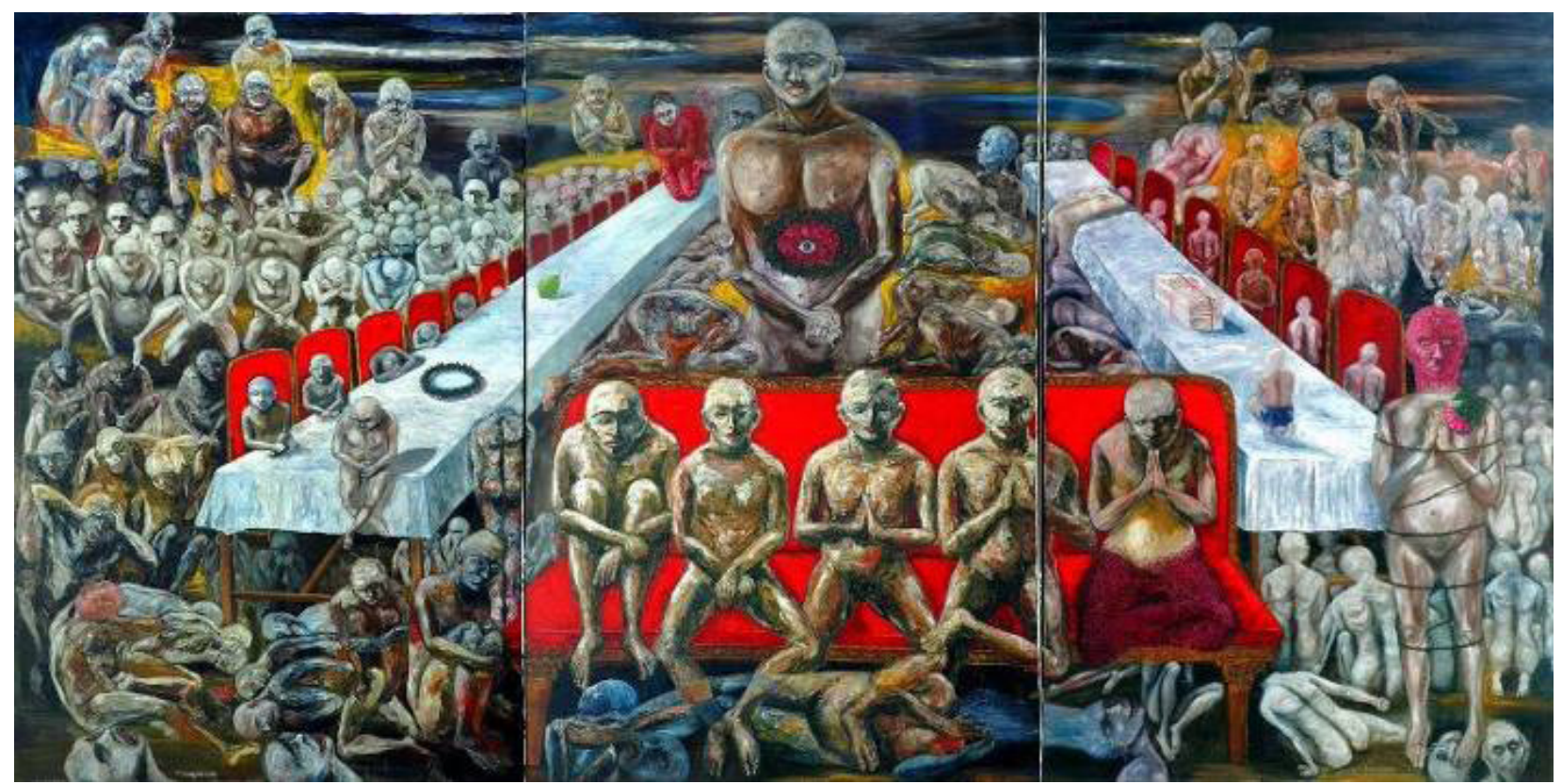

Gambar 4. Entang Wiharso, Forbidden Exotic Country, akrilik di atas kanvas (2005)

(Sumber:http://4.bp.blogspot.com/_twGwceps4xY/S_mdDJoozjl/AAAAAAAABOc/xHuPKhwYvMo/s16oo/ Forbidden+Exotic+Country,+2005.jpg)

Entang Wiharso lahir di Tegal, Jawa Tengah, pada tanggal 19 Agustus 1967. Ia lulus dari Fakultas Seni Rupa, ISI Yogyakarta tahun 1994. Sepanjang karier kesenimanannya, Entang sudah melakukan sejumlah pameran tunggal baik di dalam maupun di luar negeri. Kini ia menetap dan berkarya di Yogyakarta, sambil menjalankan studionya di Rhode Island, Amerika Serikat. Entang mendapat anugerah karya lukis terbaik dari ISI Yogyakarta selama tiga tahun berturut-turut, yaitu pada tahun 1988, 1989, dan 1990. Penghargaan lain yang diperolehnya adalah "Pratisara Affandi Adi Karya" (1994); "Juror's Award" Biennale Yogyakarta (1994); dan satu di antara "The Best Ten” Phillip Morris Indonesia Art Awards 1996. Karya-karyanya didokumentasikan dalam sejumlah buku: Konflik, Mimpi dan Tragedi Entang Wiharso (1996), Nusa Amuk: Entang Wiharso (2001), dan Hurting Landscape: Entang Wiharso (2002).

Bagi Entang Wiharso, proses penciptaan karya seni adalah tindakan berdoa dan mengingat, di samping juga proses transformasi atau melepas ketegangan emosi dan energi psikis yang tertekan melalui aktivitas berkarya seni. Melalui karyanya Entang menghadapi dan menggarap sisi gelapnya sendiri, perasaan-perasaan kelam berupa amarah, agresi, kesedihan, terror, dan ketakutan tanpa wu- jud yang lalu direpresentasikan secara visual.

Salah satu karya Entang yang memperoleh banyak ulasan adalah Forbidden Exotic Country (2005) yang terdiri dari tiga panel. Karya tersebut menjadi salah satu karya yang dijadikan sampel dalam penelitian ini karena kekuatan representasi aspek bawah sadar yang dimilikinya.

Dalam karya tersebut tampak dua meja berbentuk persegi panjang yang ditempatkan sejajar, ditutup kain putih, dan di kiri-kanannya terdapat deretan kursi berwarna merah; mengindikasikan rapat atau upacara yang sudah usai atau menjelang berlangsung. Sebagian besar kursi terlihat kosong, sementara di latar depan (foreground) terlihat sofa merah bergaya kolonial. Putihnya taplak meja, dan merahnya kursi-kursi adalah warna-warna yang berdasarkan konvensi mengingatkan pada bendera Republik Indonesia.

Secara semiotika, dua meja, deretan kursi, dan sofa menjadi petanda (signified) dari 'garis batas' nasional. Sementara ruang di bagian dalam garis batas tersebut — tempat sosok utama beradaseolah menandakan tempat suci untuk beribadah. Sosok besar yang mendominasi bidang lukisan ini memandang dengan tatapan (mengindikasikan) penuh permohonan; berlutut dengan otot-otot terlihat mengencang. Dari bagian torsonya muncul 
mata ketiga yang dikelilingi helai mahkota bunga berwarna merah jambu dan dedaunan hijau. Dalam konvensi Hinduisme, posisi mata ketiga tersebut menandai titik cakra hati pada tubuh kosmis, pusat belas-kasih.

Meski sofa itu jadi penghalang antara sosok utama dengan kita, sofa itu juga berlaku sebagai panggung yang menghadap ke arah pemirsa/apresiator. Di sofa itu duduk lima sosok laki-laki, tiga di antaranya dengan sikap semedi dalam Kebatinan Jawa/Kejawen. Di bawah pijakan kaki kelima sosok tersebut, tergeletak sesosok perempuan hamil. Kehamilan secara umum sering dipilih sebagai simbol dari regenerasi, transformasi, dan transisi yang berbahaya.

Seperti dalam kebanyakan karyanya, Entang mengaburkan identitas; bentuk manusia direduksi menjadi tipe yang repetitif. 'Tipe' manusia yang digambarkan bertatapan mata kosong, atau dengan pelototan mata maniak, sosok-sosok tanpa atribut pengenal seperti pakaian, rambut, ciri wajah yang mencolok, dan lain-lain. Sangat sering, tubuh digambarkan tanpa jenis kelamin. 'Tipe-tipe' ciptaan Entang semakin menghapus suasana realitas, menciptakan pemandangan dan adegan mimpi buruk di luar tidur. Dalam gaya, penggunaan cat, dan citraan, Entang memperlihatkan keekspresifan yang mengungkapkan kemuakan terhadap representasi yang sangat tertib dan dingin.

Ugo Untoro lahir di Purbalingga, 28 Juni 1970. Belajar seni rupa di Institut Seni Indonesia Yogyakarta sampai selesai. Dia telah berpameran tunggal sejak 1995. Ugo Untoro juga menulis puluhan cerita pendek sekali (cerpenli) yang telah diterbitkan untuk kalangan terbatas (2006). Pameran tunggalnya di Art Forum, Singapura (2007), diilhami oleh cerpenli-nya, "Short-Short Stories". Beberapa prestasi yang pernah diraihnya adalah sebagai finalis Philip Morris Indonesian Art Awards 1994, "The Best 5" Philip Morris Indonesian Art Awards 1998, dan finalis Philip Morris ASEAN Art Awards 1998 di Hanoi, Vietnam.

Karya-karya Ugo Untoro sebagaimana yang dijelaskannya, umumnya banyak didorong oleh pendekatan puitiknya karena ketertarikannya terhadap dunia sastra khususnya puisi. Banyak pihak yang kemudian menilai pendekatan puitik inilah yang banyak muncul dan menjadi ciri khas dalam karya-karya lukisnya (Kusmara, 2011).

Dengan caranya sendiri yang sangat personal Ugo menyusun kode-kode visual yang khas. Dalam sebuah wawancara ia pernah menyatakan bahwa melukis serupa dengan harapan yang mengisi kekosongan dan keluasan hati, bercampur dengan harap-harap cemas dan galau pikiran para pemancing. Mereka semua sebenarnya tak pernah tahu secara persis apa jenis dan perolehan yang akan meloncat keluar dari tiap pemancingan. Para pemancing selalu mengharapkan suatu kejutan dengan perolehan yang besar, tetapi Ugo adalah 'pemancing' yang selalu bernafsu membuat kejutan baru bagi dirinya sendiri, sesuatu yang mungkin saja sepele atau kecil bagi orang lain, tetapi menusuk hati dan pikirannya.

Ugo Untoro juga dikenal sebagai salah satu seniman yang eksentrik, salah satunya adalah kecintaannya pada kuda. Dia memiliki seekor kuda kesayangan dan bahkan sering berkeliling di sekitar Yogyakarta menunggang kudanya itu. Oleh karenanya, banyak di antara karyanya juga dilatarbelakangi inspirasi dari kuda.

Sepanjang karier Ugo Untoro sebagai seniman, tahun 2007 adalah tahun yang penting ketika ia membuat pameran yang spektakuler, Poem of Blood, di Galeri Nasional Indonesia, Jakarta. Pameran tersebut menunjukkan kompleksitas kesenian Ugo, sekaligus menunjukkan sisi yang paling personal dalam tematiknya, yaitu soal kecintaannya pada kuda. Kematian kuda kesayangan miliknya, Badai Lembut, mendorong gagasan-gagasan kuat secara artistik dan estetik dalam karya-karya pameran tunggal ini. Bahkan pameran tunggal ini kemudian menjadi salah satu pameran terbaik versi Majalah Tempo tahun 2007 (Kusmara, 2011).

Menganalisis paradigma coretannya, dapat disaksikan kecenderungan Ugo untuk tidak membuat bentuk yang selesai atau utuh. Bentuk tak utuh itu menyediakan upaya untuk berbagi ruang interpretasi; selalu masih ada ruang untuk membuat atau melengkapi tafsir atau cerita kita sendiri terhadapnya. Citra dalam lukisannya selalu tampak sebagai potongan, penggalan, atau episode tertentu 


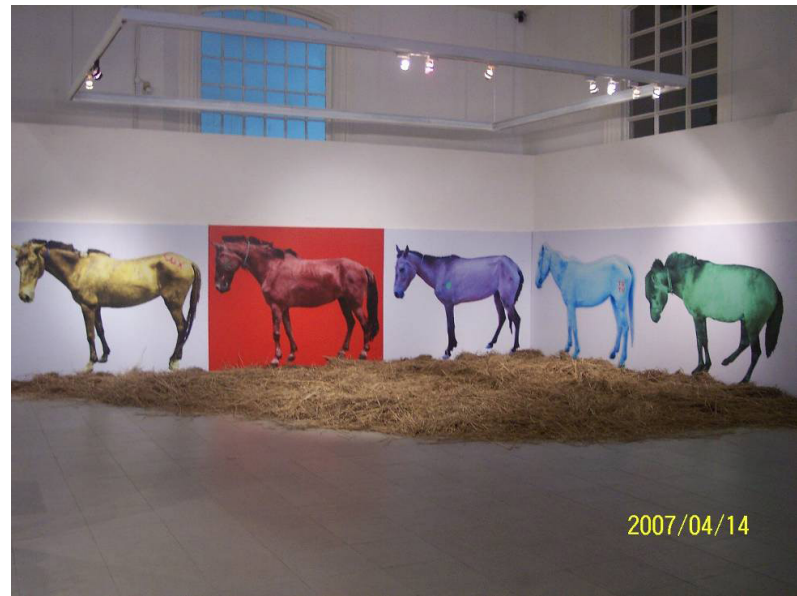

Gambar 5. Suasana pameran Poem of Blood (2007), Hall A Ruang Samping Galeri Nasional Indonesia, Jakarta. (Sumber : Dokumentasi Andryanto Rikrik Kusmara, 2007)

yang dipilih sebagai paling menggugah atau menyentuh. Citra-citra sudut dan horizon yang kosong, menghadirkan kehampaan dalam lukisannya.

Melalui representasi sosok kuda dan komposisi yang puitik Ugo mensublimasikan pengalaman traumatiknya ketika kuda kesayangannya, Badai Lembut, mati. Dalam pandangannya, kuda telah menciptakan mitos seiring dengan perkembangan peradaban manusia; dia merefleksikan perjalanan peradaban manusia yang telah menempatkannya ke tahap seperti saat ini: pemuas hasrat maskulinitas. Kuda menjadi saksi utama dari kebrutalan manusia, dan menyimpan sisi tragis kemanusiaan. Kuda tersingkir ketika ciptaan baru terlahir: mesin-mesin.

\section{Simpulan}

Berdasarkan hasil analisis terhadap karyakarya lukis ketiga seniman sampel, yaitu IGAK Murniasih, Entang Wiharso, dan Ugo Untoro, ditarik kesimpulan bahwa: (1) Aspek ketidaksadaran yang direpresentasikan dalam karya ketiga seniman sampel cenderung lahir dari pengalaman traumatik yang melahirkan ketakutan, kesakitan, dan agresi. Dalam karya Entang Wiharso dan Ugo Untoro, pengalaman dimanifestasikan melalui kemuraman sekaligus keekspresifan/kebrutalan, baik dari segi teknik maupun pertimbangan formal. Sementara itu, IGAK Murniasih memilih untuk menggambarkannya dengan penuh humor dan keceriaan; (2) Aspek ketidaksadaran direpresentasikan melalui simbol-simbol visual yang khas oleh masing-masing seniman. IGAK Murniasih melalui visualisasi organ-organ tubuh — khususnya organ seksual_sebagai bentuk katarsis sekaligus kuasa terhadap tubuhnya sendiri; Entang Wiharso melalui visualisasi tubuh-tubuh ekspresif dengan identitas yang kabur sebagai bentuk katarsis sekaligus kritik sosialnya; Ugo Untoro melalui visualisasi kuda sebagai simbol personalnya terhadap sisi tragis kemanusiaan; (3) Melukis bagi ketiganya adalah proses katarsis, yakni proses transformasi atau melepas ketegangan emosi dan energi psikis yang tertekan melalui aktivitas berkarya seni. Melukis adalah media untuk mensublimasikan/memperhalus dorongan-dorongan naluri ketakutan, kesakitan, dan agresi ke dalam bentuk karya yang dapat diterima dan diapresiasi dengan baik oleh masyarakat.

Penelitian ini baru mencakup bagian kecil dari identifikasi aspek-aspek ketidaksadaran dalam karya-karya seni rupa Indonesia. Berkaitan dengan sampel penelitian dapat dilengkapi dengan menambahkan karya-karya seni rupa dari para seniman lainnya. Diharapkan penelitian ini dapat memancing penelitian-penelitian berikutnya di bidang keilmuan psikologi seni, terutama untuk dapat menafsirkan karya-karya seni rupa Indonesia — khususnya karya seni rupa kontemporer-yang multifaset.

\section{Kepustakaan}

Adams, L.S. 1996. The Methodologies of Art: An Introduction. Boulder, Colorado: Westview Press.

Adriati, I. 2010. "Manifestasi Pola Aktualisasi Diri dalam Karya Perempuan Perupa Kontemporer Indonesia”. Disertasi Program Doktor Ilmu Seni Rupa dan Desain, Institut Teknologi Bandung.

Barrett, T. 1994. Criticizing Art, Understanding the Contemporary. California: Mayfield Publishing Company.

Freud, S. 1947. Leonardo da Vinci: A Study in Psychosexuality. New York: Random House.

Kusmara, A.R. 2011. "Medium Seni dalam Medan Sosial Seni Rupa Kontemporer Indonesia”. 
Disertasi Program Doktor Ilmu Seni Rupa dan Desain, Institut Teknologi Bandung.

Noth, W. 1995. Handbook of Semiotics. USA: Indiana University Press.

Twhaites, T. (Ed.). 1994. Tools for Cultural Studies: An Introduction. MacMillan.

Winner, E. 1982. Invented World: The Psychology of the Arts. England: Harvard University Press.

\section{Sumber dari Internet}

http//www.faculty.knox.edu

http://arsipfarahwardani.tumblr.com

http://4.bp.blogspot.com/_twGwceps4xY/S_ m d D J o o j I / A A A A A A B O c / x H u P K h w Y v M $0 /$ s $16000 /$ Forbidden+Exotic+Country,+2005.jpg 